\title{
PENGARUH AIR LIMBAH CELUPAN BATIK DI PARAKANNYASAG TASIKMALAYA TERHADAP PERTUMBUHAN KI APU (Pistia stratiotes L.)
}

\author{
Tri Cahyanto $^{1 *}$, Tony Sudjarwo ${ }^{2}$, Rida Widayanti $^{3}$, Mar'atus Shalikha $^{4}$ \\ 1,2,3 Jurusan Biologi, Fakultas Sains dan Teknologi, UIN Sunan Gunung Djati Bandung \\ Jl. AH. Nasution 105 Bandung 40614, Jawa Barat \\ ${ }^{4}$ Program Studi Pendidikan Biologi, Fakultas Tarbiyah dan Keguruan, UIN Sunan Gunung Djati Bandung \\ Jl. AH. Nasution 105 Bandung 40614, Jawa Barat
}

*Email:tri_cahyanto@uinsgd.ac.id

\begin{abstract}
Batik industry produces waste water containing chromium which can be harmful for ecosystem and human health. There had been research aimed to find out the influence of batik dye waste water in Parakannyasag Tasikmalaya on the growth of Pistia stratiotes L. Material of P. stratiotes was obtained from Indihiang rice field, Tasikmalaya. Waste water was taken from disposal of home batik dye industry in Parakannyasag Tasikmalaya. Study design used a Complete Randomized Design (RAL) with 5 treatments (0\%, 25\%, 50\%, $75 \%$ and $100 \%$ ) and 5 replications. The growth parameter include root length, leaf number, leaf length, leaf width, leaf broad, stolon number, stolon length, fresh weight and calculated of Relative Growth Rate (RGR), Doubling Time (DT) and leaf chlorophyll content were observed, The result showed growth of P. stratiotes at $25 \%$ concentration of wastewater was root length $2,2 \mathrm{~cm}$, leaf number 3,5 strands, leaf length $0,3 \mathrm{~mm}$, leaf width $0,4 \mathrm{~mm}$, leaf broad $1,7 \mathrm{~mm}$, stolon number 1,3 pieces, stolon length $1,8 \mathrm{~cm}$ and fresh weight $4,4 \mathrm{~g}$; At $50 \%$ consentration of waste water showed root length $11,2 \mathrm{~cm}$, leaf number 5,7 strands, leaf length $0,39 \mathrm{~mm}$, leaf width $0,17 \mathrm{~mm}$, leaf broad 1,3 mm, stolon number 1,6 pieces, length of stolon 2,6 cm and fresh weight 3,6 g. At $75 \%$ of waste water consentration showed, root length $5,5 \mathrm{~cm}$, lef number 4,8 strands, leaf length $-0,1 \mathrm{~mm}$, leaf width $0,1 \mathrm{~mm}$, leaf broad $-0,4 \mathrm{~mm}$, stolon number 1,1 pieces, stolon length $2,0 \mathrm{~cm}$ and fresh weight $3,0 \mathrm{~g}$; At $100 \%$ consentration of waste water showed root length $6,6 \mathrm{~cm}$, leaf number 3,8 strands, leaf length $-0,3 \mathrm{~mm}$, leaf width $-0,2 \mathrm{~mm}$, leaf broad $-0,5 \mathrm{~mm}$, stolon number 0,9 pieces, length $1,9 \mathrm{~cm}$ stolon and fresh weight $2,9 \mathrm{~g}$. The highest RGR value at $25 \%$ of wastewater concentration demonstrated $0,02 \mathrm{~g} /$ day and the highest DT value at $75 \%$ concentration of waste water demonstrated 48,0 days. The highest growth of root organs occured at $50 \%$ concentration of waste water and caused in optimum growth of $P$. stratiotes.
\end{abstract}

Keywords: Batik dye; Dobling Time; Growth; Pistia Stratiotes; Relative Growth Rate.

\section{PENDAHULUAN}

Proses pembuatan batik menggunakan bahanbahan kimia, diantaranya pewarnaan melalui pencelupan. Pewarna yang digunakan mengandung bahan-bahan kimia yaitu logam berat, padatan tersuspensi, dan zat organik. Zat pewarna batik menggunakan Naphtol dan Indigosol. Senyawa Indigosol sangat berbahaya karena dapat menyebabkan penyakit dan kanker kulit, sedangkan senyawa Naphtol merupakan zat warna tekstil yang dipakai untuk mencelup secara cepat, warna yang kuat dan tidak larut dalam air (Nugroho, 2013).

Industri batik menghasilkan limbah padat dan limbah cair. Limbah cairnya mengandung logam kromium dalam bentuk kromium heksavalen $(\mathrm{Cr}$ (VI)) dan kromium trivalen (Cr (III)) (Igwe, 2006). Keberadaan kromium di perairan dapat menyebabkan penurunan kualitas air serta membahayakan lingkungan dan organisme akuatik. Dampak yang ditimbulkan bagi organisme akuatik yaitu terganggunya metabolisme tubuh akibat terhalangnya kerja enzim dalam proses fisiologis, menumpuk dalam tubuh, dan bersifat kronis yang akhirnya mengakibatkan kematian (Puspita dkk., 2011). Keracunan krom pada manusia dapat menyebabkan ulkus pada hidung dan kulit, hiperpigmentasi pada kulit, kanker kulit, dan mengindikasi nekrosis tubulus ginjal (Panda dan Choudhury, 2005), kerusakan saluran pernafasan dan paru-paru, gangguan perut, bisul, kejang, kerusakan hati, dan bahkan kematian pada manusia (Sudarmaji dkk., 2006). Kadar krom heksavalen yang tinggi pada tumbuhan dapat mengakibatkan terjadinya hambatan pertumbuhan, menginduksi klorosis pada daun muda, mengurangi kandungan pigmen, menghambat aktivitas enzim, merusak sel 
akar dan menyebabkan modifikasi ultrastruktur pada kloroplas dan membran sel (Panda dan Choudhury, 2005).

Tanaman Ki Apu, mampu beradaptasi di dalam air dengan kadar unsur hara rendah dan tinggi. Senyawa organik maupun anorganik yang terkandung di perairan akan diserap oleh tanaman air, lalu akan terlarut ke dalam strukturnya. Kemampuan tanaman air mengurai bahan pencemar tergantung pada ketersediaan sumberdaya, keadaan lingkungan dan adaptasinya terhadap lingkungan (Syafrani, 2007). Ki Apu mempunyai karakter pertumbuhan cepat dan daya adaptasi terhadap iklim yang tinggi (Fachrurozi, 2010).

Pertumbuhan dan perkembangan $\mathrm{Ki} \mathrm{Apu}$ dipengaruhi oleh sifat fisika dan kimia air. Suhu, udara, konsentrasi dan komposisi garam dalam air memengaruhi struktur tubuh (Tanzerina dkk., 2013), beragam senyawa organik, ion, dan molekul kecil yang terlarut di dalam air digunakan untuk mempertahankan hidupnya (Fitter \& Hay, 2002).

Air limbah dapat mepengaruhi pertumbuhan Ki Apu. Air limbah deterjen dapat menurunkan kandungan klorofil pada $\mathrm{Ki} \mathrm{Apu}$ yang mengakibatkan terhambatya proses fotosintesis (Hermawati dkk., 2005). Proses fotosintesis terhambat berdampak pada penurunan jumlah asimilat yang dibentuk sehingga berat basah tumbuhan menurun. Hasil penelitian Dewi dkk. (2013) menunjukkan bahwa air limbah deterjen dapat menurunkan berat basah tumbuhan.

Hal-hal serupa di atas dapat juga dialami oleh $\mathrm{Ki}$ Apu, khususnya Ki Apu yang tumbuh pada air limbah celupan batik. Pengkajian lebih lanjut tentang variasi fisiologis atau pertumbuhan $\mathrm{Ki} \mathrm{Apu}$ pada air limbah celupan batik sangat diperlukan. Variasi yang dapat diamati mencakup perubahan ukuran, perubahan massa dan kadar klorofil.

\section{METODOLOGI PENELITIAN \\ Waktu dan Tempat}

Penelitian ini dilaksanakan pada tanggal 12 April-10 Mei 2015 di Laboraturium Kantor Lingkungan Hidup Kota Tasikmalaya dan Laboratorium Ekologi Perairan Jurusan Biologi Fakultas Sains dan Teknologi UIN Sunan Gunung Djati Bandung.

\section{Bahan dan Alat}

Peralatan yang digunakan meliputi peralatan mengukur panjang, $\mathrm{pH}$ meter, Hygrometer, Spektrofotometer UV-Vis, dan AAS. Bahan yang digunakan meliputi air limbah celupan batik yang diperoleh dari industri rumahan di Kelurahan Parakannyasag Kota Tasikmalaya. Pistia stratiotes yang seragam dengan berat antara 10-13 g dengan jumlah daun sebanyak 8 helai yang diperoleh dari persawahan Kecamatan Indihiang Kota Tasikmlaya.

\section{Metode}

Percobaan dilakukan selama 14 hari, pengujian dan pengukuran dilakukan pada hari ke-0 dan ke-14. Uji kualitas air secara kimia dan fisika dilakukan di Laboratorium Lingkungan Hidup Kota Tasikmalaya. Tanaman $P$. stratiotes yang seragam di tumbuhkan pada baskom uji yang berukuran $20 \mathrm{~L}$. Baskom uji berisi air limbah celupan batik dengan variasi konsentrasi $0 \%, 25 \%, 50 \%, 75 \%$ dan $100 \%$. Tanaman $P$. stratiotes yang digunakan pada penelitian ini sebanyak 12 individu. $P$. stratiotes di tumbuhkan pada tiap perlakuan air limbah pencelupan batik selanjutnya dilakukan pengamatan terhadap parameter pertumbuhannya. Parameter yang diamati meliputi: panjang akar (cm) terpanjang diukur dari pangkal akar hingga bagian ujung (tudung) akar; dihitung jumlah petiola kemudian diukur panjang petiola (dari puncak sampai isthmus); ukuran daun ( $\mathrm{mm}$ ) meliputi luas daun diukur pada daun urutan ke-2 dari lingkaran ke-2, panjang dan lebar daun di ukur (dari isthmus sampai apeks), dan area lamina daun (area = panjang $\mathrm{x}$ lebar $\mathrm{x} 0,85)$ persamaan diadopsi dari hasil penelitian (Sudjarwo, 2014). Perubahan ukuran daun dinyatakan dalam milimeter $(\mathrm{mm})$; panjang stolon $(\mathrm{cm})$ diukur dari pangkal hingga ke bagian ujung yang ditemui tunas baru; dan jumlah stolon dihitung yang muncul menghasilkan tunas baru; berat basah (g) diukur dengan menggunakan timbangan analitik.

Dihitung Relative Growth Rate (RGR) $P$. stratiotes yang menunjukkan laju pertumbuhan relatifnya menggunakan persamaan yang diadopsi dari penelitian Sudjarwo (2014):

$$
\mathrm{RGR}=\frac{\ln W_{2}-\ln W_{1}}{t_{2}-t_{1}}
$$

Keterangan:

$\mathrm{W} 1=$ bobot basah pengukuran pada hari ke- 0 ,

$\mathrm{W} 2$ = bobot basah pengukuran pada hari ke 14 ,

$\mathrm{T} 1=$ waktu pengukuran hari ke- 0 , dan

$\mathrm{T} 2=$ waktu pengukuran hari ke-14.

Dihitung Doubling time (DT) yang menyatakan waktu nilai bobot kering atau basah $P$ stratiotes meningkat dua kali dari semula. Persamaan diadopsi dari penelitian Sudjarwo (2014):

$$
\mathrm{DT}=\frac{\ln 2}{\mathrm{RGR}}
$$

Keterangan :

RGR : Laju Pertumbuhan Relatif. 
Uji klorofil dilakukan pada daun Pistia stratiotes hari ke-0 dan hari ke-14 dengan menggunakan metode Arnon (1949). Daun yang dipilih adalah daun pada lingkaran kedua dari bawah. Caranya, bagian daun pada lingkaran kedua dari atas diambil sebanyak $0,1 \mathrm{~g}$ dan di ekstraksi dengan cara di gerus pada lumpang dan alu yang kemudian di beri alkohol 96\%. Ekstrak kemudian di saring dengan kertas saring. Hasil saringan ditampung dalam tabung reaksi yang ditambahkan alkohol $96 \%$ hingga volumenya mencapai $10 \mathrm{~mL}$. Spektrofotometer dikalibrasi sebelum digunakan untuk mengukur klorofil di dalam ekstrak menggunakan kuvet yang di isi alkohol $96 \%$ sampai garis batas. Kemudian hal yang sama dilakukan pada ekstrak klorofil yang diperoleh dengan cara ekstrak di masukkan ke dalam kuvet sampai garis batas, lalu kuvet dimasukkan ke dalam tempatnya pada spektrofotometer. Mencatat absorbance (D) alkohol $96 \%$ (kalibrasi) dan sampel (pengukuran) pada panjang gelombang $649 \mathrm{~nm}$ dan $665 \mathrm{~nm}$. Kandungan klorofil dihitung dari nilai absorbance $(\mathrm{A}=\mathrm{D})$ hasil pengukuran spektrofotometer menggunakan persamaan (Wintermans \& de Mots 1965 dalam Harbone 2006): Klorofil-a = 13,7 D665 - 5,76 D649 (mg/L), Klorofil-b = 25,8 D649 - 7,60
D665 $(\mathrm{mg} / \mathrm{L})$, Klorofil total $=20,0$ D649 $-6,10$ D665 (mg/L).

Kualitas air limbah secara kimia yang diukur yaitu kadar kromium total SNI 6989.17:2009 secara Spektrofotometer Serapan Atom (AAS). Metode ini digunakan untuk penentuan logam krom total pada kisaran kadar $\mathrm{Cr}$ 0,2 mg/L sampai dengan $10 \mathrm{mg} / \mathrm{L}$ dan panjang gelombang 357,9 $\mathrm{nm}$. Serta kualitas air limbah secara fisika yaitu dengan mengukur $\mathrm{pH}$ dan suhu air limbah yang dilakukan setiap hari.

\section{Analisis Data}

Data dianalisis dengan Analisis Variansi (Anava) untuk melihat signifikansi perlakuan yang dilanjutkan dengan Duncan Mean Range Test (DMRT). Anava dan DMRT menggunakan software SPSS versi 16 pada taraf nyata $(\alpha) 5 \%$.

\section{HASIL DAN PEMBAHASAN}

\section{A. Hasil}

Hasil penelitian meliputi kandungan krom total (Tabel 1.), perubahan pertumbuhan Ki Apu (Tabel 2.), Relative Growth Rate (RGR) dan Dobling Time (DT) (Tabel 3.) dan Perubahan klorofil Ki Apu pada air limbah celupan batik di Parakannyasag Tasikmalaya (Tabel 4.).

Tabel 1. Kandungan krom total pada air limbah celupan batik di Parakannyasag Tasikmalaya

\begin{tabular}{ccc}
\hline Konsentrasi Air Limbah Celupan Batik $(\%)$ & Krom (Cr) Total \\
\hline 0 & $0,018^{\mathrm{a}}$ & $0,587^{\mathrm{b}}$ \\
25 & $1,053^{\mathrm{bc}}$ & $1,023^{\mathrm{bc}}$ \\
50 & $1,414^{\mathrm{c}}$ \\
\hline
\end{tabular}

Keterangan : Angka yang diikuti huruf yang sama pada kolom menunjukkan tidak berbeda nyata pada taraf $(\alpha) 5 \%$.

Tabel 2. Perubahan Pertumbuhan Ki Apu pada Air Limbah Celupan Batik di Parakannyasag Tasikmalaya

\begin{tabular}{|c|c|c|c|c|c|c|c|c|}
\hline \multicolumn{9}{|c|}{ Perubahan Pertumbuhan } \\
\hline $\begin{array}{c}\text { Konsentrasi Air Limbah } \\
\text { Celupan Batik } \\
(\%)\end{array}$ & $\begin{array}{c}\text { Panjang } \\
\text { Akar } \\
\text { (cm) }\end{array}$ & $\begin{array}{l}\text { Jumlah } \\
\text { Daun } \\
\text { (helai) }\end{array}$ & $\begin{array}{l}\text { Panjang } \\
\text { Daun } \\
(\mathrm{cm})\end{array}$ & $\begin{array}{l}\text { Lebar } \\
\text { Daun } \\
(\mathrm{cm})\end{array}$ & $\begin{array}{l}\text { Luas Daun } \\
\qquad\left(\mathrm{cm}^{2}\right)\end{array}$ & $\begin{array}{l}\text { Jumlah } \\
\text { Stolon }\end{array}$ & $\begin{array}{l}\text { Panjang } \\
\text { Stolon } \\
(\mathrm{cm})\end{array}$ & $\begin{array}{c}\text { Berat } \\
\text { Basah } \\
(\mathbf{g})\end{array}$ \\
\hline 0 & $2,1234^{\mathrm{a}}$ & $2,7668^{\mathrm{a}}$ & $0,0618^{\mathrm{bc}}$ & $0.1618^{b}$ & $0.6006^{\mathrm{b}}$ & $1,2002^{\mathrm{b}}$ & $1,9948^{\mathrm{a}}$ & $5.4032^{\mathrm{b}}$ \\
\hline 25 & $2,1902^{\mathrm{a}}$ & $3,4832^{\mathrm{ab}}$ & $0,2700^{\mathrm{cd}}$ & $0.4232^{\mathrm{c}}$ & $1,7170^{\mathrm{c}}$ & $1,2666^{\mathrm{b}}$ & $1,8284^{\mathrm{a}}$ & $4.4210^{\mathrm{ab}}$ \\
\hline 50 & $11,2118^{\mathrm{c}}$ & $5,6666^{\mathrm{d}}$ & $0,3884^{\mathrm{d}}$ & $0.1682^{\mathrm{b}}$ & $1,3112^{c}$ & $1,5998^{\mathrm{c}}$ & $2,6384^{b}$ & $3.5980^{\mathrm{ab}}$ \\
\hline 75 & $5,5384^{b}$ & $4,7668^{\mathrm{c}}$ & $-0.0640^{\mathrm{ab}}$ & $-0.1146^{\mathrm{a}}$ & $-0.3508^{a}$ & $1,1334^{\mathrm{ab}}$ & $1,9800^{\mathrm{a}}$ & $2.9518^{\mathrm{a}}$ \\
\hline 100 & $6,5518^{\mathrm{b}}$ & $3,7502^{\mathrm{b}}$ & $-0.2500^{\mathrm{a}}$ & $-0.1600^{a}$ & $-0.5054^{\mathrm{a}}$ & $0,9334^{\mathrm{a}}$ & $1,9434^{\mathrm{a}}$ & $2.9142^{\mathrm{a}}$ \\
\hline
\end{tabular}

Tabel 3. Relative Growth Rate (RGR) dan Dobling Time (DT) Ki Apu pada air limbah celupan batik di Parakannyasag Tasikmalaya.

\begin{tabular}{ccc}
\hline $\begin{array}{c}\text { Konsentrasi Air Limbah Celupan } \\
\text { Batik (\%) }\end{array}$ & Relative Growth Rate (RGR) (\%) & Dobling Time (DT) (hari) \\
\hline 0 & $0,0290^{\mathrm{b}}$ & $24,5186^{\mathrm{a}}$ \\
25 & $0,0236^{\mathrm{ab}}$ & $32,9450^{\mathrm{ab}}$ \\
50 & $0,0204^{\mathrm{ab}}$ & $36,1890^{\mathrm{ab}}$
\end{tabular}


Tabel 4. Perubahan klorofil Ki Apu pada air limbah celupan batik di Parakannyasag Tasikmalaya.

\begin{tabular}{cccc}
\hline $\begin{array}{c}\text { Konsentrasi Air Limbah Celupan } \\
\text { Batik } \\
(\boldsymbol{\%})\end{array}$ & $\begin{array}{c}\text { Plorofil-a } \\
(\mathbf{m g} / \mathbf{L})\end{array}$ & $\begin{array}{c}\text { Perubahan Kadar Klorofil } \\
\text { Klorofil-b } \\
(\mathbf{m g} / \mathbf{L})\end{array}$ & $\begin{array}{c}\text { Klorofil Total } \\
(\mathbf{m g} / \mathbf{L})\end{array}$ \\
\hline 0 & $-0,7984^{\mathrm{a}}$ & $-0,3484^{\mathrm{a}}$ & $-1,1290^{\mathrm{ab}}$ \\
25 & $-0,3730^{\mathrm{cd}}$ & $0,1826^{\mathrm{c}}$ & $-0,0151^{\mathrm{c}}$ \\
50 & $-0,0944^{\mathrm{d}}$ & $0,0824^{\mathrm{bc}}$ & $-0,0185^{\mathrm{c}}$ \\
75 & $-0,8952^{\mathrm{a}}$ & $-0,3894^{\mathrm{a}}$ & $-1,2831^{\mathrm{a}}$ \\
100 & $-0,5562^{\mathrm{bc}}$ & $-0,1428^{\mathrm{a}}$ & $-0,6984^{\mathrm{b}}$ \\
\hline
\end{tabular}

Keterangan : Angka yang dikiuti huruf yang sama pada kolom menunjukkan tidak berbeda nyata pada taraf $(\alpha) 5 \%$.

\section{B. Pembahasan}

Krom merupakan salah satu logam berat yang berbahaya yang dihasilkan dari industri batik. Hasil pengukuran logam berat $\mathrm{Cr}$ pada air limbah pencelupan batik di Kelurahan Parakannyasag Kota Tasikmalaya menunjukkan berbeda nyata (Tabel 1).

Berdasarkan Tabel 1, kandungan krom total air limbah celupan batik cenderung meningkat dengan peningkatan konsentrasinya. Kadar krom total berkurang dengan adanya pengenceran. Logam berat krom menunjukkan bahwa konsentrasi $100 \%$ mempunyai kadar krom yang paling tinggi yaitu sebesar 1,414 mg/L. Sedangkan kadar krom terendah pada konsentrasi $0 \%$ sebesar $0,018 \mathrm{mg} / \mathrm{L}$. Krom total pada konsentrasi air limbah celupan batik $25 \%$ sebesar $0,587 \mathrm{mg} / \mathrm{L}, 50 \%$ sebesar $\quad 1,053$ $\mathrm{mg} / \mathrm{L}$, dan $75 \%$ sebesar $1,023 \mathrm{mg} / \mathrm{L}$. Perubahan nilai kadar krom setiap konsentrasi air limbah celupan batik rata-rata $0,364 \mathrm{mg} / \mathrm{L}$.

Hasil rata-rata kadar logam berat krom pada setiap konsentrasi menunjukkan bahwa konsentrasi $0 \%$ tidak berbeda nyata terhadap semua konsentrasi. Konsentrasi $25 \%$ tidak berbeda nyata dengan konsentrasi $50 \%$ dan $75 \%$ tetapi berbeda nyata dengan konsentrasi $0 \%$ dan $100 \%$. Konsentrasi $50 \%$ tidak berbeda nyata dengan konsentrasi $25 \%, 75 \%$ dan $100 \%$ tetapi berbeda nyata dengan konsentrasi $0 \%$.

Hasil pengukuran kadar krom pada air limbah pencelupan batik Kelurahan Prakannyasag Kota Tasikmalaya pada konsentrasi 25-100\% menunjukkan kadar krom diatas baku mutu yaitu sebesar 0,59-1,41 mg/L. Menurut Peraturan Pemerintah Republik Indonesia Nomor 82 Tahun 2001 menyatakan bahwa baku mutu krom total pada air limbah pencelupan batik adalah $0,05 \mathrm{mg} / \mathrm{L}$.

Hasil pengukuran menunjukkan bahwa keberadaan krom pada air limbah pencelupan batik
Parakannyasag Kota Tasikmalaya sangat berbahaya karena melibihi batas baku mutu yang telah ditentukan di dalam PP Nomor 82 Tahun 2001. Keberadaan kromium di perairan dapat menyebabkan penurunan kualitas air serta membahayakan lingkungan dan organisme akuatik (Puspita dkk., 2011). Haryanti dkk. (2009), menyatakan bahwa Logam berat merupakan salah satu faktor yang memengaruhi pertumbuhan tumbuhan. Adanya logam berat pada tempat hidup suatu tumbuhan akan memengaruhi pertumbuhan tumbuhan air. Perubahan pertumbuhan Ki Apu pada air limbah celupan batik di Parakannyasag Kota Tasikmalaya dapat dilihat pada Tabel 2.

Berdasarkan Tabel 2, diperoleh nilai-niai pertumbuhan tertinggi $\mathrm{Ki} \mathrm{Apu}$, yaitu panjang akar sebesar 11,2118 cm, jumlah daun sebesar 5,6666 helai, jumlah stolon sebesar 1,5998 dan panjang stolon sebesar 2,6384 cm. Nilai-nilai pertumbuhan tersebut menunjukkan ukuran yang tertinggi pada perlakuan konsentrasi $50 \%$ air limbah celupan batik. Luas daun sebesar $1,7170 \mathrm{~cm} 2$ dan berat basah sebesar 4,4210 g merupakan nilai-nilai pertumbuhan yang menunjukkan ukuran tertinggi pada konsentrasi $25 \%$ air limbah celupan batik.

Nilai ukuran berat basah tanaman Ki Apu yang lebih tinggi pada konsentrasi $25 \%$ dan $50 \%$ air limbah celupan batik. Nilai tersebut membuktikan bahwa konsentrasi krom tidak menggangu metabolisme Ki Apu. Pernyataan ini didukung oleh penelitian Hapsari dkk. (2016) bahwa terjadi pertumbuhan yang baik pada tanaman Ki Apu pada medium limbah dengan konsentrasi krom $20 \%$, yaitu berat basah terukur sebesar $11,10 \mathrm{~g}$.

Tanamana $\mathrm{Ki}$ Apu mengalami gangguan metabolisme karena mengalami cekaman krom pada perlakuan limbah dengan konsentrasi $75 \%$ dan 100\%. Gangguan metabolisme tanaman $\mathrm{Ki} \mathrm{Apu}$ 
dijelaskan dari rendahnya nilai berat basah (dalam gram) dan menurunnya pertumbuhan daun bahkan sampai minus $(-0,3508$ dan $-0,5054 \mathrm{~cm} 2)$. Kondisi tersebut kemungkinan disebabkan oleh perendaman selama 14 hari dalam media konsentrasi krom tinggi. Pemaparan dalam waktu lama menyebabkan Ki Apu mengalami penurunan kemampuan produksi fitokelatin (Ulfin dan Widya, 2005). Penurunan fitokelatin ini disebabkan karena rusaknya jaringan sel dalam akar. Fitokelatin sendiri merupakan enzim tanaman yang mampu berikatan dengan logam. Kemampuan Ki Apu dalam memecah krom dan membentuk kelat ion logam (Safarrida dkk., 2015), sehingga tanaman Ki Apu sering digunakan sebagai agen fitoremediasi.

Kemampuan toleransi tanaman Ki Apu terhadap krom memang lebih rendah dari pada Eichhornia crassipes dan Salvinia sp. Tanaman Ki Apu dalam paparan media krom 4 ppm akan mengalami perubahan kenampakan fisik, yaitu timbulnya bercak coklat pada daun serta megalami kekeringan. Kondisi tersebut berbeda jika dibandingkan E. crassipes yang masih bisa bertahan dalam paparan media krom 8 ppm (Safarrida dkk., 2015). Adaptasi yang kurang baik tersebut berdampak pada penurunan kamampuan menyerap krom oleh $\mathrm{Ki}$ Apu dibandingkan dengan tanaman Salvinia natans (Thilakar dkk., 2012).

Nilai Relative Growth Rate (RGR) Ki Apu menyatakan laju pertumbuhan relatif. Sedangkan Doubling Time (DT) Ki Apu adalah waktu yang menyatakan nilai bobot basah organisme sehingga meningkat dua kali lipat. Hasil pengukuran RGR dan DT pada air limbah celupan batik di Kelurahan Parakannyasag Kota Tasikmalaya menunjukkan berbeda nyata (Tabel 3).

Berdasarkan Tabel 3, RGR dan DT Ki Apu tertinggi pada konsentrasi $50 \%$ air limbah celupan batik. Peningkatan konsentrasi 0 hingga $100 \%$ air limbah celupan batik menunjukkan nilai ukuram RGR menurun, dan nilai ukuran DT meningkat lalu menurun.

Berdasarkan Tabel 4, nilai klorofil daun Ki Apu, kebanyakan menunjukkan penurunan, baik Klorofila, klorofi-b, maupun klorofil total. Pengamatan khusus pada klotofil total, peningkatan konsentrasi 0 ke $100 \%$ air limbah celupan batik menunjukkan nilai ukurannya menurun lalu meningkat.

Penurunan kandungan klorofil-a, klorofil-b, dan klorofil total hampir terjadi di semua perlakuan. Hasil yang sama juga ditunjukkan dalam penelitian Das dkk. (2014), terjadi penurunan kandungan klorofil-a, -b dan klorofil total tanaman Ki Apu pada konsentrasi krom 5, 10, dan $100 \mu \mathrm{M}$. Penurunan tersebut menunjukkan rusaknya jaringan pada daun dan batang tanaman Ki Apu. Kondisi tersebut terjadi karena tanaman mengalami kejenuhan akibat hiperakumulasi krom dalam jaringan akar. Kondisi jenuh menyebabkan tanaman tidak mampu membentuk kelat ion logam. Penurunan pembentukan kelat logam menyebabkan krom sisa yang bersifat toksik masuk ke dalam jaringan yang lebih dalam sampai ke batang dan daun, sehingga sel mengalami klorosis. Pengikatan logam berat dengan fitokelat $\mathrm{Ki} \mathrm{Apu}$ akan terakumulasi di bagian akar bukan di daun (Sugiyanto dkk., 1991), sehingga mengurangi perjalanan krom ke bagian daun. Mekanisme akumulasi kelat ion logam di jaringan akar terjadi melalui proses rhizofiltrasi (Prajapati dkk., 2012; Thilakar dkk., 2012).

Kadar krom di dalam jaringan tanaman $\mathrm{Ki} \mathrm{Apu}$ dapat memengaruhi metabolismenya. Hal tersebut terjadi seperti pada tanaman kacang kedele. Studi Sundarmoorthy dkk. (2015) pada kacang kedele, krom dapat memengaruhi pigmen fotosintetik, yaitu klorofil-a, klorofil-b, dan klorofil total; biomolekul di dalam sel, yaitu asam amino, protein, gula, dan prolin; serta diperkirakan memengaruhi aktivitas enzimatik antioksidan, yaitu katalase, peroksidase, polifenol oksidase, dan super oksida dismutase.

$\mathrm{Ki}$ Apu menunjukkan gejala akibat paparan krom pada air limbah celupan batik. Nilai-nilai pengukuran klorofil-a, klorofil-b, dan klorofil total kebanyakan menunjukkan negatif, artinya mengalami pengurangan kadar pada hari ke-14. Ada dua nilai positif kadar klorofil daun $\mathrm{Ki} \mathrm{Apu}$, yaitu nilai klorofil-b pada konsentrasi air celupan batik sebesar $25 \%$ dan 50\%, namun nilainya kecil berturut-turut $0,1826 \mathrm{mg} / \mathrm{L}$ dan $0,0824 \mathrm{mg} / \mathrm{L}$ bila dibandingkan dengan yang mengalami penurunan kadar klorofil daun Ki Apu pada klorofil-a, klorofilb, dan klorofil total lainnya (Tabel 4). Akumulasi krom juga dapat dilihat pengaruhnya pada RGR dan DT Ki Apu. Nilai konsentrasi air limbah celupan batik makin tinggi menurunkan RGR dan memperlama DT. Hal ini menandakan efek nyata dari tiga aspek pertumbuhan, yaitu produksi pigmen fotosintetik, biomolekul, dan aktivitas enzimatik anti oksidan terganggu.

$\mathrm{Ki}$ Apu masih mampu hidup atau bahkan beradaptasi dalam paparan air limbah celupan batik. Kemampuan tersebut didukung dengan adanya komponen asam organik dan methallothionein. Keduanya merupakan komponen penting tumbuhan yang berperan dalam mekanisme toleran dan detoksifikasi racun (Panda dan Choudhury, 2005). 


\section{KESIMPULAN}

Ki Apu mengalami pertumbuhan optimum pada konsentrasi $50 \%$ air limbah celupan batik di Parakannyasag Tasikmalaya dengan pertumbuhan tertinggi pada panjang akar sebesar $11,2 \mathrm{~cm}$, jumlah daun 5,7 helai, panjang daun $0,4 \mathrm{~mm}$, jumlah stolon 1,6 buah dan panjang stolon sebesar 2,6 cm. Akar merupakan bagian organ yang memiliki nilai pertumbuhan paling tinggi dibandingkan dengan nilai pertumbuhan bagian lainnya pada Ki Apu.

\section{UCAPAN TERIMAKASIH}

Terima kasih kepada Bapak Asep yang telah menyediakan bahan air limbah celupan batik di Parakannyasag Tasikmalaya, serta Pejabat dan Staf di Kantor Dinas Lingkungan Hidup Tasikmalaya yang telah membimbing dan menyediakan laboratorium dalam menguji kadar krom total dan pengukuran klorofil.

\section{DAFTAR PUSTAKA}

[1] Das, B.C., Panda, A., Sahoo, P.K., Jena, S. \& Padhi, P. 2014. Effect of chromium (VI) on wheat seedlings and the role of chelating agent. J. Current Science, 106(10): 13871393.

[2] Dewi, R.K., Winy, R.M. \& Andi, Z. (2013). Efektivitas dan Efisiensi Fitoremediasi Orthofosfat pada Deterjen Menggunakan Kiambang (Pistia stratiotes). Program Studi Manajemen Sumber Daya Air, Fakultas Ilmu Kelautan dan Perikanan, Universitas Kelautan Raja Haji Ali, Hlm 7.

[3] Fachrurozi, M., Utami, L.B. \& Suryani, D. (2010). Pengaruh Variasi Biomassa Pistia stratiotes L. terhadap Penurunan Kadar BOD, COD, dan TSS Limbah Cair Tahu Dusun Klero Sleman Yogyakarta. Jurnal KES MAS UAD. 4 (1): 1-14.

[4] Fitter. A.H. \& Hay R.K.M. (1981). Fisiologi Lingkungan Tanaman (Terjemahan). Gadjah Mada University Press, Yogyakarta. Hlm 385.

[5] Hapsari, S., Zaman, B. \& Andarani, P. 2016. Kemampuan Tumbuhan Kayu Apu (Pistia Stratiotes L.) Dalam Menyisihkan Kromium Total (Cr-T) Dan COD Limbah Elektroplating. Jurnal Teknik Lingkungan, 5(4): 1-9.

[6] Hermawati, E., Wiryanto \& Solichatun. (2005). Fitoremediasi Limbah Detergen Menggunakan Kayu Apu (Pistia Stratiotes L.) dan Genjer (Limnocharis Flava, L.). Bio Smart 7(2): 121-122.

[7] Igwe, J.C \& Abia, A.A. (2006). A Bioseparation Process for Removing Heavy Metals from Waste Water Using Biosorbent. African Journal of Biotechnology 5(12): 1167-1179.

[8] Jagtap, M.V., Kulkarni, and P. R. Puranik. (2011). Accumulation Of Heavy Metals and Concurrent Physiological Changes In Hydrophytes M. N. Adv. Pharmacol. Toxicol. 12(1): 41-49.

[9] Mufarrege, M.M., H. R. Hadad and M. A. Maine. (2010). Response of Pistia stratiotes to Heavy Metals (Cr, Ni, and $\mathrm{Zn}$ ) and Phosphorous. Arch Environ Contam Toxicol, 58:53-61

[10] Nugroho, S. (2013). Elektrodegradasi Indigosol Golden Yellow Irk dalam Limbah Batik dengan Elektroda Grafit. Skripsi. Semarang. Jurusan Kimia Fakultas Matematika dan Ilmu Pengetahuan Alam, Universitas Negeri Semarang. 1-10.

[11] Odjegba, V.J. and I.O. Fasidi. 2004. Accumulation of Trace Elements by Pistia Stratiotes: Implications for Phytoremediation Ecotoxicology, Kluwer Academic Publishers, 13: 637-646.

[12] Panda, S.K. \& Choundhury, S. (2005). Chromium Stress In Plant. Brazilian Journal Of Plant Physiology. 17(1): 95-102.

[13] Panda S.K \& Patra H.K. 2000. Nitrate And Ammonium Ions Effect On The Chromium Toxicity In Developing Wheat Seedlings. $P$ Natl Acad Sci India B, 70:75-80.

[14] Peraturan Pemerintah Republik Indonesia Nomor 82 Tahun 2001 Tentang Pengelolaan Kualitas Air dan Pengendalian Pencemaran Air.

[15] Prajapati, S.K., Meravi, N. \& Singh, S. 2012. Phytoremediation of Chromium and Cobalt using Pistia stratiotes: A Sustainable Approach. Proceedings of The International Academy of Ecology and Environmental Sciences, 2(2): 136-138.

[16] Puspita, U.R., Siregar, A.S., \& Hidayati, N.V. (2011). Kemampuan Tumbuhan Air Sebagai Agen Fitoremediator Logam Berat Kromium 
(Cr) Yang Terdapat Pada Limbah Cair Industri Batik. Jurnal Berkala Perikanan Terubuka. 39(1): 58-59.

[17] Safarrida, A., Ngadiman. \& Widada, J. 2015. Fitoremediasi Kandungan Kromium Pada Limbah Cair Menggunakan Tanaman Air. J. Bioteknologi \& Biosains Indonesia, 2(2): 5559Shah, A.B., U.N. Rai, and R.P. Singh. (2015). Correlation Between Some Hazardous Inorganic Pollutans in the Gomti River and Their Accumulation in Selected Macrophytes Under Aquatic Ecosystem. Bull Environment Contam Toxicol, 94: 783-790.

[18] Srivastava S., Mishra S., Dwivedi S., Baghel V.S., Verma S., Tandon P.K., Rai U.N. and Tripathi R.D. (2005). Nickel Phytoremediation Potential Of Broad Bean, Vicia faba L. and its biochemical responses. Bull Environ Contam Toxicol 74: 715-724.

[19] Sudarmadji, Mukono, J. \& Corie, I.P. (2006). Toksikologi Logam Berat B3 Dan Dampaknya Terhadap Kesehatan. Jurnal Kesehatan Lingkungan. 2(2): 129-142.

[20] Sudjarwo,T., Nisyawati, Rossiana, N. \& Mangunwardoyo, W. (2014). The growth of water hyacinth (Eichhornia crassipes (Mart.) Solms) and water lettuce (Pistia stratiotes L.) in domestic wastewater in wastewater treatment plant (WWTP) Bojongsoang, Bandung, Indonesia. Journal of Biodiversity and Environmental Sciences (JBES). 5(4): 393-401.
[21] Sugiyanto, T., Darussalam, M. \& Nurhidayat N. 1991. Pemanfaatan Gulma Air untuk Menanggulangi Pencemaran Limbah Aktif Cr-51. Makalah disajikan pada Proceedings Seminar Reaktor Nuklir dalam Penelitian Sains dan Teknologi menuju Era Tinggal Landas, Bandung, 8-10 Oktober 1991. PPTNBATAN.

[22] Sundarmoorthy, P., Sankarganesh, K. Selvaraj, M. Baskaran, L. \& Chidambaram, A.A. 2015. Chromium induced changes in Soybean (Glycine max L.) metabolism. World scientific News 10: 145-178.

[23] Syafrani. (2007). Kajian Pemanfaatan Media Penyaring dan Tumbuhan Air setempat untuk Pengendalian Limbah Cair pada Sub-Das Tapung Kiri, Propinsi Riau. Disertasi. Sekolah Pascasarjana. Institut Pertanian Bogor. 2007.

[24] Tanzerina, N., Juswardi \& Elyza, F. (2013). Studi Adaptasi Anatomi Organ Vegetatif Neptunia oleraceae Lour Hasil Seleksi Lini pada Fitoremediasi Limbah Cair Amoniak. Prosiding Semirata FMIPA. Universitas Lampung, Hlm: 165-173.

[25] Thilakar, R.J., Rathi, J. \& Pillai P.M. 2012. Phytoaccumulation of Chromium and Copper by Pistia stratiotes L. and Salvinia natans (L.) All. J. Nat. Prod. Plant Resour., 2(6): 725730.

[26] Ulfin I. \& Widya, W. 2005. Studi Penyerapan Kromium Dengan Kayu Apu (Pistia stratiotes, L). J Akta Kimindo. 1(1): 41-48. 